\title{
Yemen: Mellemøstens syge mand
}

\section{Martin Ledstrup}

Det sydarabiske korthus Yemen er udsat for et stormvejr af sammenfaldende kriser, der presser Saleh-regimet på flere fronter. Den yemenitiske stats svaghed er imidlertid også udslag af en helt særegen, magtpolitisk formular, der har rødder i landets tumultariske fortid

Udfordringen til staten som den primære geopolitiske aktør er ret beset ikke kun et træk, der udmærker sig ved fejlslagne og fejlslående stater. Tendensen er bredere end som så et træk ved globaliseringen. For visse stater er problematikken imidlertid decideret akut.

Dette bidrag zoomer ind på et stormombrust korthus: Republikken Yemen. Den seneste øgede opmærksomhed på landet er velbegrundet, om end det herskende perspektiv, som har drejet sig om al-Qaeda på den arabiske halvø, slører de væsentligste udfordringer mod den yemenitiske stat og landets stabilitet - en pointe, som jeg vil forsøge at argumentere for gennem følgende diagnose af Mellemøstens syge mand.
Inden vi ser nærmere på denne, er det imidlertid først på sin plads at illustrere symptomerne herpå.

Set gennem en vestlig antiterroroptik er det første i nyere tid blandt andet hændelsen i december 2009, hvor en nigerianer ved navn Umar Farouk Abd al-Mutallab satte sig i flyet mod Detroit og forsøgte at detonere medbragte sprængstoffer. Senere skød en amerikansk major Nidal Malik Hassan - en håndfuld kollegaer på Fort Hood, Texas. De to hændelser havde tilfælles, at begge individer havde den samme mand i Yemen som deres åndelige mentor: Anwar al-Awlaki, der har dobbelt amerikansk-yemenitisk statsborgerskab og en kandidatuddannelse fra Colorado State University. 
Det er også ham, der står bag lanceringen af det nye militante islamistiske magasin Inspire der blandt andre har Kurt Westergaard, Flemming Rose og Carsten Juste på deres dødsliste.

Al-Qaedas fornyede styrke, der også har udmærket sig i adskillige andre angreb på blandt andet den amerikanske ambassade i Sana'a i 2008, afstedkommer bekymring blandt vestlige magthavere og overskrifter i medierne. De fleste yemenitter har imidlertid alvorligere udfordringer at slås med, og de fleste har aldrig hørt om Anwar al-Awlaki.

\section{Ny radikalisering}

Der er imidlertid ingen tvivl om, at den nye generation af militante islamister i Yemen er mere radikaliserede imod det yemenitiske regime end nogensinde før. For det første fordi de er blevet ekskluderet herfra i modsætning til den ældre generation af militante islamister, der blev pacificerede gennem integration i militæret og sikkerhedsapparatet efter tilbagevenden fra Afghanistan i slutningen af $1980^{\circ}$ erne. Og for det andet fordi Saudi-Arabien har bekæmpet deres egne militante islamister så effektivt, at de er flygtet til Yemen.

Men når den almindelige yemenit ikke deler Vestens bekymringer, så er det fordi, al-Qaeda på den arabiske halvø på mange måder er parasitter på en generel, yemenitisk radi- kalisering, som er forankret i en række faktorer, der er ganske distinkte fra militant islamisme. I nord hersker en borgerkrig, der - foruden at være et potentielt scenario for regionale rivaliseringer mellem Saudi-Arabien, Qatar og Iran - har sendt mindst en kvart million mennesker på flugt. Og flere flygtede, da Saudi-Arabien tog regimets parti, skred til direkte militær intervention, og bombede kombattanter såvel som civile (i øvrigt med britisk leverede jagerfly). Det hele startede som et oprør fra en shia-islamistisk bevægelse i 2004, og selvom kampene pt. står i bero, så har regimets brutale magtdemonstrationer for længst udvidet konfliktens spændvidde til noget meget andet, mere og dybere end konfliktens oprindelige udspring.

I syden florerer en voksende separatistbevægelse, der ønsker at løsrive sig efter 20 års udbytning, og truer med at rive det Yemen, vi kender $\mathrm{i}$ dag, over på midten.

Regimet slår hårdt ned og udnytter ofte den globale terrorfortælling hertil: pågrebne eller dræbte separatister italesættes af regimet som terrormistænkte, hvilket mere eller mindre trofast vidererapporteres af de internationale pressetjenester, mens vestlige og arabiske såvel som yemenitiske journalister er udelukket fra at nærme sig sandheden.

Det er på den måde en temmelig kompliceret opgave at anslå al-Qaedas styrke. Hvor mange af dem, der 
kaldes terrormistænkte, er i virkeligheden separatister? I hvor høj grad er det yemenitiske regimes udmeldinger om al-Qaeda også en del af et forsøg på at kandidere til flere og flere amerikanske donorpenge, som eksempelvis de 1,7 milliarder USD i militær bistand, der lige er blevet stillet i udsigt? Og hvor meget af denne militære bistand vil regimet rent faktisk rette mod al-Qaeda frem for mod regimets andre modstandere?

\section{På kanten af kollaps}

Spørgsmålet om behovet for donorpenge knytter an til det mest alvorlige symptom på den yemenitiske stats svaghed: det afkræftede regime balancerer økonomisk på kanten af kollaps.

Landets olieressourcer, der står for 75 procent af indtægtsgrundlaget, forventes at tørre ud inden 2020. Yemen står ligeledes til at løbe tør for det, den franske sociolog Marcel Mauss har kaldt et socialt totalfaktum, fordi manglen på det berører alt: vand. Sana'a, der vokser med 7 procent om året, spås at blive den første hovedstad i verden, der løber tør for vand. Imens - og som en konsekvens heraf - vokser al-Qaedas styrke med landets deroute, fordi de målrettet forsøger at monopolisere den tornado af socioøkonomisk og politisk nag, hvis radius vokser for hver dag der går.

Når jeg imidlertid anser Yemens strukturelle udfordringer for mere primære end al-Qaeda i relation til statens svaghed, så hænger det sammen med de ejendommeligheder, som kendetegner yemenitisk politik. Et andet vigtigt forhold hedder 'Saudi-Arabien' - et forhold, som vi skal se nærmere på om et øjeblik.

Men først et par ord om Yemens magtpolitiske formular. Vi taler om et anpartsselskab: et politisk fornuftsægteskab, der ikke sammenbindes af nogen form for religiøs eller ideologisk konvergens, men tværtimod af et cirkulært forhold mellem regimet og de yderst potente stammeoverhoveder, som bestikkes, inkluderes og privilegeres mod til gengæld at repræsentere centralmagten i periferien.

Hvorfra kommer denne konstellation? Fra Yemens tumultariske fortid - en tumult, der startede, da den republikanske avantgarde kastede det shia-islamiske Imamat fra magten i 1962.

\section{Stedfortræderkrig}

Revolutionen resulterede i en blodig borgerkrig, der på samme tid også var en regional stedfortræderkrig mellem Egypten (på republikansk side) og Saudi-Arabien (på Imamatets side). Som borgerkrigen skred frem, tippede det politiske momentum fra magtkampen mellem republikanerne og royalisterne i centrum til en magtkamp mellem de to fraktioners stammestøtter i pe- 
riferien. Stammerne havde dogdengang som i dag - ikke noget specifikt ideologisk indhold, og deres alliancer var derfor flydende og et langt stykke ad vejen til salg for den politiske aktør, der kunne forsyne dem med de mest favorable subsidier og løfter om fortsat autonomi. Der går talrige historier om, hvordan to stammer aftalte at alliere sig med hver sin fraktion for derefter at dele udbyttet og ellers fortsætte som hidtil.

I 1970 sluttede borgerkrigen i republikanernes favør dels ved en fredsaftale mellem de stridende parter, dels ved at magtfulde stammeoverhoveder indtog (eller blev bestukket med) magtfulde positioner.

I midten af $1970^{\prime}$ erne forsøgte den teknokratiske, moderniserende præsident Ibrahim al-Hamdi dog at udbygge statsmagten på stammernes bekostning, men på trods af hans betydelige folkelige popularitet, kostede det ham livet. Efter al-Hamdi (og en parentes ved navn Ahmad alGhasmi, som også blev snigmyrdet) fulgte imidlertid Saleh - en usædvanlig kløgtig pragmatiker, der stadig sidder på magten.

Når dette er tilfældet, er det således ikke fordi han forsøgte at etablere statsmagtens monopol over yemenitiske forhold - snarere tværtimod. Landets stabilitet kom til at afhænge af et kompromis mellem de moderniserende kræfter i statsmagten på den ene side, og en række ikke-statslige, traditionalistiske aktører på den anden side: det yemenitiske magtapparats legitimitet blev afhængig af periferiens tribale kræfter. På den måde synes der umiddelbart at knytte sig to misforståelser til Yemen som en fejlslagen stat.

\section{Fravær af stat}

Den første er, om vi overhovedet kan tale om en yemenitisk stat i konventionel forstand, fordi en sådan netop defineres som en politisk entitet med monopol på administration og den legitime voldsudøvelse. Et sådant monopol har aldrig eksisteret i Yemen - om end dette (netop som en følge af stat-stamme-cirkulariteten) ikke nødvendigvis har resulteret i statens illegitimitet. Indtil for nylig har fraværet af staten på store dele af det yemenitiske territorium heller ikke været ensbetydende med lovløshed og radikalisering - en ellers ret så central antagelse i det meste af diskursen om fejlslagne stater - men snarere en alternativ (stamme) orden.

Den anden misforståelse, som florerer i offentligheden, er at truslen mod den yemenitiske stat først og fremmest relaterer sig til al-Qaeda. Heller ikke dette lader til at være tilfældet. Derimod synes den yemenitiske version af statsmagten at hvile på Ali Abd Allah Saleh's evne til at fastholde og manipulere alle de følsomme balancer, som udmærker det yemenitiske anpartsselskab. De største udfordringer imod det er ikke al- 
Qaeda, men derimod det, den militante islamisme lukrerer på: landets gryende politiske kaos og regimets krympende, strukturelle manøvrerum.

En anden faktor er som nævnt den saudiske kongefamilie, fordi denne altid har frygtet konsolideringen af en republikansk, folkerig, relativt demokratiseret modfortælling til kongerigets hegemoni på den Arabiske Halvø.

I 1991 smed Saudi-Arabien eksempelvis godt en million yemenitiske gæstearbejdere ud af landet - tilsyneladende fordi præsident Saleh, der på daværende tidspunkt sad i FN's sikkerhedsråd, undlod at stemme for eller imod verdenssamfundets indgriben over for Saddam Husseins overgreb på Kuwait. Saudiernes beslutning havde dog meget lidt at gøre med Salehs manglende stemme. Til gengæld havde den formentlig mere at gøre med, at Nordog Sydyemen blev forenet i 1990, og saudierne frygtede den nydannede yemenitiske stat.

Saudiernes træk virkede, og den yemenitiske statsøkonomi imploderede. Stammernes økonomi og styrke forblev imidlertid intakt, fordi saudierne fortsatte (og fortsætter) deres generøse donationer til stammernes politiske momentum, der som nævnt altid har været en politisk kæp i hjulet på konsolideringen af en konventionel yemenitisk stat.

Symptomerne på den yemenitiske stats svaghed forefindes altså i tre lag. I det øverste eliterivalisering; i det midterste to borgerkrige og et genfødt al-Qaeda på den Arabiske Halvø; i det nederste et ulmende, strukturelt kaos. Det er i dette net af kriser, det yemenitiske regime er udspændt. Diagnosen herpå er kompleks, men specifikt i forhold til statens svaghed kan der i hvert fald peges på to afgørende forhold: landets helt særegne politiske formular og Saudi-Arabien - den mest magtfulde eksterne aktør i yemenitiske forhold. Der hænger blåsorte skyer over Det (u)lykkelige Arabien, og det er svært at vide, hvad de bringer med sig. Som et minimum er det dog værd at pege på, hvordan de befinder sig i både det lokale, subregionale såvel som internationale luftlag.

Martin Ledstrup har last arabisk og mellemøststudier ved Yemen College of Middle Eastern Studies samt varet $i$ forskningspraktik ved det franske institut $i$ Sana'a. Han er endvidere stifter og medredaktør af bloggen 'Det (u)lykkelige Arabien', og skriver pt. speciale om saudi-yemenitiske relationer. 